\title{
Feasibility of growing conventional confectionary sunflower hybrids in organic agriculture: preliminary results of organic trials
}

\author{
Brankica Babec ${ }^{1 *} \cdot$ Nada Hladni' ${ }^{1}$ Srđan Šeremešić ${ }^{2}$ Milan Jocković1 $\cdot$ Nemanja Ćuk ${ }^{1}$. \\ Sonja Gvozdenac ${ }^{1}$. Vladimir Mikličc · Bojan Vojnov ${ }^{2}$
}

${ }^{1}$ Institute of Field and Vegetable Crops, Maksima Gorkog 30, Novi Sad, Serbia

¿University of Novi Sad, Faculty of Agriculture, Dositej Obradović Square 8, Novi Sad, Serbia

\begin{abstract}
Summary: As organic agriculture represents one of the most sustainable ways of agricultural land use, the key purpose of this research was to improve confectionary sunflower production in organic agriculture. The trial compared seed yield per plant of conventional confectionary sunflower hybrids in organic vs conventional production. Subsequently, 1000 seed weight, seed yield per plant and kernel ratio of confectionary hybrids treated with the following fertilizers used in organic production: fertilizer of animal origin $(G)$, fertilizer based on amino acids and nitrogen (T) and microbiological fertilizer $(\mathrm{N})$ were compared with untreated control $(\mathrm{C})$. Fertilizers enhanced yield of sunflower compared to untreated control; the highest yield was recorded in combined of $\mathrm{G}+\mathrm{N}$ and $\mathrm{G}+\mathrm{T}$, all in organic agriculture system. NS Gricko had the lowest seed yield per plant compared to the other hybrids that significantly increased when treated with $\mathrm{G}+\mathrm{N}$ fertilizers; same results were obtained in treatments of NS Slatki, and NS Leviathan. Preliminary results of the study indicated that application of organic fertilizers can have a positive effect on yield of sunflower in organic production conditions, which indicates that further research is necessary.

Key words: sunflower, organic farming, fertilizing, seed yield, 1000 seed weight
\end{abstract}

\section{Introduction}

Organic agriculture is a steadily growing sector on a global scale. It lowers the environmental costs of agriculture and delivers numerous other public benefits, especially in the spheres of management of natural resources and viability of rural areas (Niggli et al., 2008). The reports covering global research recognize organic agriculture as a farming system that balances sustainability goals and tends to have great importance in global food and ecosystem security (National Research Council,

\section{Corresponding author:}

brankica.babec@ifvcns.ns.ac.rs

Acknowledgement:

This study is conducted in cooperation with the Center for Organic Production Selenča within the project entitled "Realization of research and development activities from idea to implementation with the aim of improving the production of organic producers", which was supported by the Serbian National Agency for Regional Development, November 2015 - June 2016.

\section{Cite this article:}

Babec B., Hladni N., Šeremešić S., Jocković M., Ćuk N., Gvozdenac S., Miklič V., Vojnov B. (2019). Feasibility of growing conventional confectionary sunflower hybrids in organic agriculture: preliminary results of organic trials. Ratar. Pourt., 56 (1), 26-33.
2010; Nam, 2015). Areas under the organic production and market size of organic food are constantly increasing (Reganold and Wachter, 2015). Currently, $1.2 \%$ of the world's agricultural land is organic. According to Willer and Lernoud (2018) there are more than 58 million hectares of organic agriculture land including in conversion areas, and Europe is the second world's region covering $23 \%$ with such production. Overall area under organic production in Europe grew by $21 \%$ between 2010 and 2015 to $6.2 \%$ of total used agricultural area (Eurostat, 2016) and further growth is expected. Growing share of areas under organic agricultural system indicate that the consumers show a developing interest in food production that favor nature conservation and human health. Still, all these strengths may not be enough because research shows that yields in organic agriculture are lower compared to conventional agriculture.

Increasing demand for healthy food in Republic of Serbia (RS) has led to the conversion of conventional farms to organic, which significantly contributed to increasing the overall sustainability of agricultural production (Lazić and Šeremešić, 2010). Between 2010 and 2015, areas under organic production in RS increased 
from 5.855 ha to 15.298 ha (Simić, 2017). The organization of overall agricultural production in RS is influenced by economical and agro-ecological conditions and characteristics of rural areas. Field crops including pastures and meadows have the largest contribution in organic production in RS $(68.7 \%)$, while cereals occupy $31.7 \%$, followed by fruit production (Golijan et al., 2017; Simić, 2017). As the production of confectionary sunflower does not closely relate to organic production, the research of this crop in organic agriculture systems has the importance.

Considerable part of the world's annual production of sunflower seed is used for confectionary and snack food, bird and pet food, so the market demands for it are in constant increase (Hladni, 2016). Even though sunflower hybrids are mainly grown for vegetable oil, confectionary sunflower is the preferred type in Turkey, US, Canada, China, Pakistan, Iran, etc. (Pekcan et al., 2015). However, confectionary type of sunflower is scarcely present in the EU countries (Nabloussi et al., 2011), which offers great opportunity for the producers to convert areas under the conventional sunflower into the organic, and in this way raise the value of this product.

Confectionary hybrids should have high genetic potential for seed yield $>5 \mathrm{t} / \mathrm{ha}$, high self-fertility rate, resistance to diseases and broomrape, and good nutritional values (Jocić et al., 2015; Hladni, 2016). In addition, they should be adaptable to environmental conditions and suitable for growing in different agroecological conditions which are characteristic of organic agriculture. Uniform and timely field germination and emergence are therefore very important for a good crop stand of sunflower, while fertile soil, obtained by using organic fertilizers, is vital to achieving good plant health and seed quality (Jalaluddin, 2011).

Yield stability across years is also very important and can be a solution to overcoming yield gap between organic and conventional agriculture. Research on sunflower yield in organic production systems is poor, but analysis of yield stability reported by Knapp and van der Heijden (2018) shows that fertilization can help reduce the overall yield stability gap between conventional and organic agriculture, confirming that production under the conditions of organic agriculture needs to develop applicable and suitable nutrient management, able to address all the plant growth requirements. Shahzaman (2017) indicated that utilization of organic fertilizers can produce better growth of sunflower crops and improve overall production, if applied timely.

The aim of the study was to compare sunflower yields under the conditions of organic and conventional agriculture and to determine the effects of different organic fertilizers on seed yield and yield components of conventional confectionary sunflower hybrids under the conditions of organic agriculture. The objective of three different fertilization treatments (Guanito (G),
Guanito+Naturplasma $(\mathrm{G}+\mathrm{N})$, Guanito+Trainer $(\mathrm{G}+\mathrm{T})$ ) was to compare them with untreated control, all under the conditions of organic agriculture, and to recommend the cultivars with promising prospects for this sector.

\section{Materials and Methods}

For the purpose of comparing sunflower yields under the conditions of organic and conventional agriculture, five NS confectionary sunflower hybrids developed at the Institute of Field and Vegetable Crops Novi Sad (NS Leviathan, NS Slatki, NS Gricko, NS Argonaut, and NS Vitez) were sown on a conventionally and also on organically managed plots.

On the conventional plot soybean was the preceding crop, and the plot was deeply plowed after harvest and fertilized with mixed NPK fertilizer (50:50:50) in accordance with soil analysis. The assay was set in the same way as on organic plot without treatment with organic fertilizers. The basic agrochemical analyses of the soil were made at the same time and method as on organic plot. The soil was loamy clay, soil $\mathrm{pH}(\mathrm{KCl})$ was $6.17, \mathrm{AL}_{-} \mathrm{P}_{2} \mathrm{O}_{5}$ was $6.2 \mathrm{mg} 100 \mathrm{~g}^{-1}$ and $\mathrm{AL}-\mathrm{K}_{2} \mathrm{O}$ was $20.9 \mathrm{mg} 100 \mathrm{~g}^{-1}$. Total $\mathrm{N}$ was $0.143 \%$ and organic matter content $1.66 \%$, all less than at the organic plot.

Apart from comparisons with conventional production, the goal of sowing on an organic parcel was to study seed yield per plant, kernel ratio and 1000 seed weight of conventional confectionary sunflower hybrids treated with the following commercially available fertilizers:

1. Organic fertilizer of animal origin containing $6 \%$ organic $\mathrm{N}, 15 \% \mathrm{P}_{2} \mathrm{O}_{5}, 3 \% \mathrm{~K}_{2} \mathrm{O}, 27.5 \%$ organic $\mathrm{C}$, 4.6 C/N ratio, and $3.5 \%$ of humic acid - Guanito (G),

2. Amino acid $(31.3 \%)$ and Nitrogen $(5 \%$ of total $\mathrm{N}$ (organic)) liquid fertilizer for foliar application, energetically active, that helps plant overcome climatic stress situations as common conditions of organic production - Trainer $(\mathrm{T})$,

3. Microbiological fertilizer consisting of green microalgae Chlorella vulgaris. The solution, as determined by the algae, contains macro, mezo, microelements, vitamins, as well as essential and non-essential amino acids - Natur Plasma $(\mathrm{N})$.

All the applied fertilizers are listed in the list of registered products for plant nutrition in organic agriculture, issued by Plant Protection Directorate of the Ministry of Agriculture, Forestry and Water Management.

The experiment was set up in 2016 at the Center for Development of Organic Production in Selenča (RS) as a random block system with 3 repetitions where basic plot size was $6 \times 22.4 \mathrm{~m}$ or $134.4 \mathrm{~m}^{2}$. The preceding crop was maize certified for organic production. Seedbed preparation consisted of plowing at $30 \mathrm{~cm}$ and light field cultivation. Treatment with the 
fertilizer Guanito, $0.5 \mathrm{t} \mathrm{ha}^{-1}$, was performed at the stage BBCH 01 (Meier, 2001), while treatments with Natur Plasma, $51 \mathrm{ha}^{-1}$, and Trainer, $31 \mathrm{ha}^{-1}$, were carried out at the stage $\mathrm{BBCH}$ 36. Sample plants for analysis were taken from the central rows (excluding the outermost plants). Seed yield per plant was determined by measuring total seed quantity in each individual open pollinated plant using a laboratory scale. Examination of 1000 seed weight as repeated 3 times, and each time 2 times 200 seeds were used. The obtained value was applied to 1000 seed weight and was specified in grams. Sample size was 20 plants per replication. The analyses were carried out at the level of the plant.

The basic agrochemical analyses of the soil were carried out during September (before harvest), and samples were collected from the topsoil $(0-30 \mathrm{~cm}) ; 2-3$ composite soil samples were taken from every plot under the different treatment, each consisting of 10 individual samples. According to the FAO classification, the soil belongs to chernozem soil type and it is loamy clay concerning its texture class (according to Tommerup). Analyses showed no difference in soil $\mathrm{pH}$ values between treatments. All treatments had sufficient available $\mathrm{AL}-\mathrm{P}_{2} \mathrm{O}_{5}$ and $\mathrm{AL}$ $\mathrm{K}_{2} \mathrm{O}$. Total $\mathrm{N}$ and organic matter content showed slight differences in treatments. Overall higher parameters of soil fertility were found in general.

Data were analyzed using two-way ANOVA (analysis of variance) to differentiate sunflower characteristics in relation to the hybrid, treatment and their interaction. Data were processed in the statistical software SPSS (IBM, 2016). For correlations to be identified between the measured traits, data sets were processed using Principal Component Analysis (PCA) (Pearson, 1901). The PCA tries to summarize the data of traits in fewer variables (the PC-axis or factors). The first PC-factor (PC 1) is a linear combination of all traits in the analysis such, that it covers the largest part of the variance in all traits. The remaining variation which is independent of the PC 1 variable is then explained by the next PC-factor (PC 2) to explain most of the remaining variation in a linear combination of the trait variable. In this way, a large part of the variation can be explained in only two variables. Data were processed in PAST software (Hammer et al., 2001) for scientific data analysis.

\section{Results and Discussion}

Studies of Pitelkow et al. (2015) and Knapp and van der Heijden (2018) showed that yield gap between sustainable and conventional agricultural systems may be overcome by enhancement of yield stability throughout years. Also, agricultural practices such as fertilization, plowing, hoeing, cultivation irrigation, and interaction of other measures with selected genotypes can reduce the difference in yield gap and promote organic agriculture as the system that will provide food with fewer environmental tradeoffs. This research evaluated seed yield per plant in organic production relative to conventional production. As expected, T-test indicated statistical significance in the case of seed yield per plant. By comparison of the averages, it can be concluded that an overall significantly higher seed yield per plant was obtained in conventional production relative to all hybrids (Table 1). T-test showed differences in hybrids respectively to organic and conventional production. Statistically significant differences in seed yield per plant under conventional conditions were obtained in hybrid NS Gricko and NS Leviathan. Hybrid NS Argonaut had bigger seed yield per plant in organic system, but not statistically significant, and NS Vitez had the lowest reduction rate in organic conditions comparing to other hybrids (Table 2).

Seed yield of sunflower is the product of several different yield components. Using the two-way analysis of variance, the study aimed to assess the main effect of each independent variable and their interaction in organic

Table 1. T-test indicating the differences in seed yield per plant in organic production relative to conventional production

\begin{tabular}{lcccc}
\hline Type of production & Average seed yield per plant & $\mathrm{t}$ & $\mathrm{d}$ & $\mathrm{p}$ \\
\hline Organic production & $\begin{array}{l}73.67 \pm 14.14 \\
88.76 \pm 29.34\end{array}$ & -2.53 & 48 & 0.02 \\
Conventional production & & & \\
\hline
\end{tabular}

Average value \pm standard deviation; $\mathrm{t}$ - difference between two groups;

$\mathrm{df}$ - degrees of freedom; $\mathrm{p}$ - calculated probability

Table 2. T-test indicating the differences in seed yield per plant relative to hybrids in organic and conventional production

\begin{tabular}{lccc}
\hline Hybrids & Organic production $(\mathrm{g})$ & Conventional production $(\mathrm{g})$ & $\mathrm{t}$ \\
\hline NS Gricko & $84.00 \pm 10.11$ & $110.00 \pm 5.65$ & $-2.65^{*}$ \\
NS Slatki & $75.33 \pm 6.11$ & $89.00 \pm 12.73$ & -1.69 \\
NS Leviathan & $57.33 \pm 11.22$ & $97.50 \pm 0.71$ & $-3.79 *$ \\
NS Argonaut & $70.33 \pm 6.81$ & $58.00 \pm 7.07$ & 1.94 \\
NS Vitez & $81.33 \pm 12.63$ & $89.33 \pm 0.58$ & -1.64 \\
\hline
\end{tabular}

Average value \pm standard deviation; $\mathrm{t}$ - difference between hybrids; ${ }^{\mathrm{p}}<0.05$ 
Table 3. Two-way ANOVA for identifying the differences in the sunflower characteristics in organic production

\begin{tabular}{lccc}
\hline & $\Lambda$ & $\mathrm{F}$ & $\mathrm{p}$ \\
\hline Treatment & 0.57 & 1.23 & 0.25 \\
Hybrid & 0.00 & 21.27 & 0.00 \\
Interaction $\mathrm{T} \times \mathrm{H}$ & 0.03 & 20.07 & 0.04 \\
\hline
\end{tabular}

$\Lambda$ - Wilks' Lambda; F - variance of the group means; $\mathrm{p}$ - calculated probability; $\mathrm{T}$ - treatment; $\mathrm{H}$ - hybrid

production system. The differences in sunflower characteristics are significantly contributed by the hybrids and interactions of hybrids and treatments (organic fertilizers), but the treatments between themselves had no significant effect (Table 3). Therefore, the assumption is to test the differences of NS confectionary hybrids in organic production.

Significant differences were observed across hybrids concerning seed yield per plant, kernel ratio, and 1000 seed weight (Table 4). Interaction of treatments and hybrids was significant for seed yield per plant (Table 4). Pang and
Letely (2000) stated that to have plant-available $\mathrm{N}$ at the time and in the quantity required by specific genotypes proved crucial to achieving high yields. Results of other research pointed out that the highest-yielding genotypes grown in conventional agriculture are not the highestyielding genotypes in organic agriculture (Murphy et al., 2007). All of the above indicates that further research is needed concerning the impact of fertilizers on specific hybrids, which proved to be the best under organic production conditions.

Table 5 indicates that organic fertilizers negatively contributed to seed yield per plant in hybrid NS Gricko, i.e. this hybrid has the lowest seed yield statistically significant compared to the other hybrids. Considering interactions with treatments, it can be concluded that higher seed yields per plant were observed in the following combinations: $\mathrm{G}+\mathrm{N} \times$ NS Gricko, $\mathrm{G}+\mathrm{N} \times \mathrm{NS}$ Slatki, $\mathrm{G}+\mathrm{N} \times \mathrm{NS}$ Leviathan and $\mathrm{G}+\mathrm{T} \times \mathrm{NS}$ Argonaut (Table 5). Lower seed yields per plant (regarding other hybrids) were observed in following combinations: $\mathrm{G} \times \mathrm{NS}$ Argonaut, $\mathrm{G} \times \mathrm{NS}$ Argonaut and $\mathrm{G}+\mathrm{T} \times \mathrm{NS}$ Gricko (Table 5).

Table 4. The differences in sunflower traits across hybrids and interactions of hybrids with treatments

\begin{tabular}{llccc}
\hline & & $\mathrm{F}$ & $\mathrm{df}$ & $\mathrm{p}$ \\
\hline Hybrid & Seed yield per plant & 4.54 & 4 & 0.00 \\
& Kernel ratio & 79.54 & 4 & 0.00 \\
& 1000 seed weight & 37.52 & 4 & 0.00 \\
\hline Interaction $\mathrm{T} \times \mathrm{H}$ & Seed yield per plant & 7.16 & 12 & 0.00 \\
& Kernel ratio & 0.20 & 12 & 0.99 \\
& 1000 seed weight & 0.77 & 12 & 0.68 \\
\hline
\end{tabular}

F - variance of the group means; $\mathrm{df}$ - degrees of freedom; $\mathrm{p}$ - calculated probability; $\mathrm{T}$ - treatment; $\mathrm{H}$ - hybrid;

Table 5. Overview of interaction hybrids $\times$ organic fertilizer for seed yield per plant

\begin{tabular}{|c|c|c|c|c|}
\hline & & b slope & $\mathrm{t}$ & $\mathrm{p}$ \\
\hline Seed yield & NS Gricko & -21.08 & -3.63 & 0.02 \\
\hline \multirow[t]{24}{*}{ per plant } & NS Slatki & -6.99 & -0.87 & 0.39 \\
\hline & NS Leviathan & 0.76 & 1.67 & 0.40 \\
\hline & NS Argonaut & -1.16 & -1.03 & 0.31 \\
\hline & NS Vitez & $*$ & $*$ & $*$ \\
\hline & $\mathrm{C} \times \mathrm{NS}$ Gricko & * & $*$ & * \\
\hline & $\mathrm{C} \times$ NS Slatki & * & * & * \\
\hline & $\mathrm{C} \times$ NS Leviathan & $*$ & $*$ & $*$ \\
\hline & $\mathrm{C} \times \mathrm{NS}$ Argonaut & * & $*$ & $*$ \\
\hline & $\mathrm{C} \times \mathrm{NS}$ Vitez & $*$ & $*$ & $*$ \\
\hline & $\mathrm{G} \times$ NS Gricko & 0.25 & 0.37 & 0.68 \\
\hline & $\mathrm{G} \times$ NS Slatki & 12.94 & 1.14 & 0.26 \\
\hline & $\mathrm{G} \times \mathrm{NS}$ Leviathan & -29.37 & -4.68 & 0.01 \\
\hline & $G \times N S$ Argonaut & -33.35 & -4.17 & 0.01 \\
\hline & $G \times$ NS Vitez & $*$ & $*$ & $*$ \\
\hline & $\mathrm{G}+\mathrm{N} \times \mathrm{NS}$ Gricko & 25.65 & 3.26 & 0.03 \\
\hline & $\mathrm{G}+\mathrm{N} \times \mathrm{NS}$ Slatki & 52.52 & 3.99 & 0.01 \\
\hline & $\mathrm{G}+\mathrm{N} \times \mathrm{NS}$ Leviathan & 39.04 & 3.71 & 0.05 \\
\hline & $\mathrm{G}+\mathrm{N} \times \mathrm{NS}$ Argonaut & 19.18 & 4.33 & 0.06 \\
\hline & $\mathrm{G}+\mathrm{N} \times \mathrm{NS}$ Vitez & $*$ & $*$ & $*$ \\
\hline & $\mathrm{G}+\mathrm{T} \times \mathrm{NS}$ Gricko & -35.43 & -4.48 & 0.03 \\
\hline & $\mathrm{G}+\mathrm{T} \times \mathrm{NS}$ Slatki & 13.82 & 1.83 & 0.10 \\
\hline & G+T $\times$ NS Leviathan & 13.65 & 1.20 & 0.24 \\
\hline & $\mathrm{G}+\mathrm{T} \times \mathrm{NS}$ Argonaut & 34.69 & 3.05 & 0.01 \\
\hline & $\mathrm{G}+\mathrm{T} \times \mathrm{NS}$ Vitez & * & * & * \\
\hline
\end{tabular}

b slope - constant; $\mathrm{t}$ - difference between two groups and the difference within the groups; $\mathrm{p}$ - calculated probability; C - Control; G - Guanito; $\mathrm{G}+\mathrm{N}$ - Guanito+Naturplasma; G+T - Guanito+Trainer; * - indicate the reference group in relation to which the other groups of factors and interactions were automatically compared 


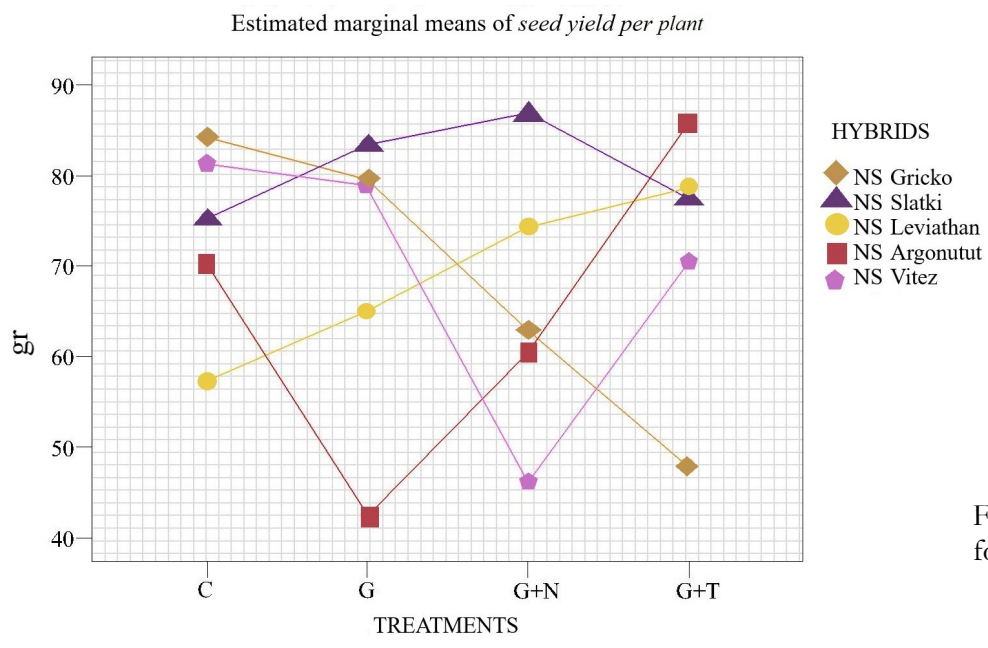

Figure 1 implies that hybrid NS Slatki has stable and the highest seed yield per plant depending on the treatment compared to other tested hybrids. The figure also indicates that hybrid NS Vitez had the most variable seed yield per plant.

Singh (2012) pointed out that the processes that maintain organic matter $(\mathrm{OM})$ are fundamental for sustainable agriculture and productivity of agroecosystems. Soil OM involves different soil processes, such as those linked to nutrient cycle, biological activity, diversity and soil structure, so utilization of organic fertilizers is a cultivation practice and an approach which can help saving $\mathrm{OM}$ in both the short and long-term. Pang and Letely (2000) stated that the use of organic fertilizers causes soil changes other than fertility influence, which can improve plant growth. Results of Kramer et al. (2006) showed that the use of organic fertilizers will reduce adverse nitrate leaching.

Nitrogen is a meaningful plant nutrient needed for high yields of most industrial crops, but usually a limiting factor for accomplishing high crop yields (Panga and Letely, 2000; Đukić et al., 2014). Nitrogen deficiency decreases vegetative and generative growth which can lead to reduced yields (Ozer et al., 2004). It was reported that NPK fertilization can raise seed yield and yield components of sunflower (Zubillaga et al., 2002; Ruffo et al., 2003; Ozer et al., 2004). Our study showed that treatment with nitrogen fertilizers $(\mathrm{G}+\mathrm{T})$ in combination with microbiological fertilizer (N) application significantly increased seed yield per plant for hybrids NS Gricko, NS Slatki, NS Leviathan which is in accordance with similar research. Ruffo et al. (2003) reported a significant effect of $\mathrm{N}$ on seed yield and seed number per plant. Various studies in different agroecological conditions also pointed out the positive response to $\mathrm{N}$ fertilization of sunflower seed yield and yield components (Scheiner and Lavado, 1999; Halvorson et al., 1999; Ruffo et al., 2003).

As already mentioned, there were no differences in soil $\mathrm{pH}(\mathrm{KCl})$ ranging from 7.28 in treatment $\mathrm{G}$ to 7.35 in treatment $\mathrm{G}+\mathrm{T}$. In general, there were no significant differences in soil $\mathrm{pH}$ values between different organic systems, which is similar to the results obtained in other studies (Liebig and Doran, 1999; Gosling and Shepherd, 2005, Čuvardić et al., 2006). All treatments had sufficient available AL- $\mathrm{P}_{2} \mathrm{O}_{5}$ that ranged from $17.3 \mathrm{mg} 100 \mathrm{~g}^{-1}$ in treatment $\mathrm{G}$ to $18.9 \mathrm{mg} 100 \mathrm{~g}^{-1}$ in $\mathrm{C}$, and $\mathrm{AL}-\mathrm{K}_{2} \mathrm{O}$ that was $22.7 \mathrm{mg} 100 \mathrm{~g}^{-1}$ in treatment $\mathrm{G}$ to $24.4 \mathrm{mg} 100 \mathrm{~g}^{-1}$ in $\mathrm{G}+\mathrm{T}$. Total $\mathrm{N}$ and organic matter content was partially affected by the treatments, so treatment $\mathrm{G}+\mathrm{N}$ showed the highest results $(0.193 \%$ total $\mathrm{N} ; 2.6 \%$ organic matter $)$ compared to $\mathrm{C}(0.183 \%$ total $\mathrm{N})$ respectively treatment $\mathrm{G}$ $(2.33 \%$ organic matter). Generally higher parameters of soil fertility were found in treatments $\mathrm{G}+\mathrm{N}$ and $\mathrm{G}+\mathrm{T}$.

With adaptation of the management practices significant number of characteristics of cultivated sunflower can be improved, but it is very important to find appropriate correlations depending on the desired trait. It is also important to know the relationships between yield components, their relationship to yield, and the alteration of the individual components under the influence of the environment. All the obtained data were analyzed with PCA to allow correlations to be observed in the space of the components which are available, i.e. in the space of sunflower parameters collected during the trial. The PCA was performed to have a better understanding about the relationships of the variables. The first step was to standardize the data by transforming the data set into the $\mathrm{z}$ -scores. The PC biplot reflected $82.4 \%$ of the variation corresponding to $50.8 \%$ (PC 1) and 31.6\% (PC 2), with Eigen value greater than 1 (Table 6 ). Table 6 shows that

Table 6. Eigen values and proportion of total variability as well as correlation based on traits in five sunflower hybrids

\begin{tabular}{llc}
\hline & PC 1 & PC 2 \\
\hline Eigen value & 53.38 & 33.12 \\
Proportion of variance & 50.80 & 31.60 \\
\hline Traits & \multicolumn{2}{c}{ Eigen Vector } \\
\hline Seed yield per plant & 0.35 & 0.91 \\
Kernel ratio & 0.69 & -0.10 \\
1000 seed weight & 0.64 & -0.39 \\
\hline
\end{tabular}




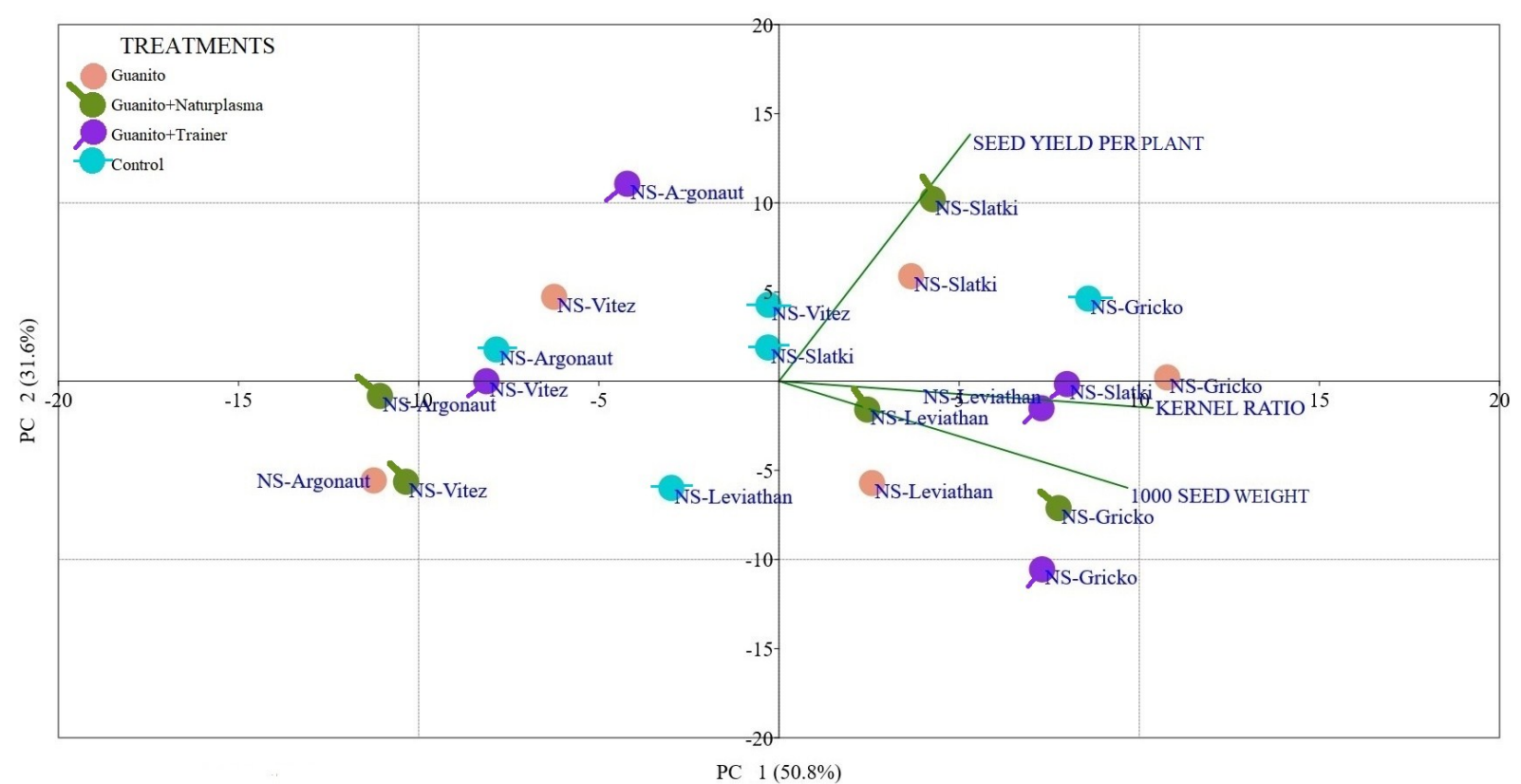

Figure 2. PCA biplot showing correlations between components for interaction of hybrids $\times$ treatment

the traits which contributed more positively to PC 1, were kernel ratio (Eigen vector 0.69) and 1000 seed weight (Eigen vector 0.64), and the trait which contributed more positively to PC 2 were seed yield per plant (Eigen vector 0.91).

Distribution of the 5 confectionary sunflower hybrids along the first and second principal components based on measured traits is presented in Figure 2. According to vector angles on the biplot analyzed traits have shown positive correlation (Figure 2). According to the vector angles (angle smaller than $90^{\circ}$ indicates that the variables are positively correlated) 1000 seed weight and kernel ratio were in positive correlation, which can be explained by the fact that seeds with higher kernel ratio have a greater mass. Yield is more complex trait because it depends on several other traits. Thousand seed weight and kernel ratio were also in positive correlation with seed yield per plant, but the angle among 1000 seed weight and seed yield per plant was almost $90^{\circ}$ which indicates that the correlation is not that strong, it almost does not exist. Lopez-Pereira et al. (1999) and Marinkovic et al. (2003) also suggested that 1000 seed weight was not significantly correlated with seed yield per plant. Thousand seed weight is a very variable trait and is found under the influence of genetic, as well external environmental factors (Joksimović et al., 2004, Škorić, 2012). Grain traits were more important than yield, considering the fact that this research included confectionary sunflower hybrids.

Correlation coefficient analysis confirms the above presented results. Namely, 1000 seed weight and kernel ratio were in positive correlation that was statistically significant $(p=0.0451 *)$. These two traits $(1000$ seed weight and kernel ratio) were also in positive correlation with seed yield per plant but not statistically significant $(\mathrm{p}=0.762 ; \mathrm{p}=0.394$, respectively).

\section{Conclusions}

In order to make use of all currently available resources, including fertilizers registered for organic agriculture, the results of the trial provided evidence that application of certified organic fertilizers are able to sustain the yield of sunflower under the conditions of organic agriculture. In relation to that it can be concluded that hybrid NS Slatki can be recommended for future research in organic agriculture conditions. NS Gricko, along with NS Slatki and NS Argonaut, had the lowest seed yield compared to the other hybrids, but also increased seed yield per plant when treated with Guanito in combination with Trainer i.e. Naturplasma. The obtained results have practical importance considering favorable agroecological condition for organic production of confectionary sunflower. Future research needs to focus on selection of fertilizers to meet the requirement of specific hybrids.

\section{References}

Čuvardić, M., Šeremešić, S., Novaković, N. (2006). Soil Fertility in Organic Farming in the First Years After Transition. Joint Organic Congress, Odense, Denmark, May 30-31

Đukić, V., Balešević Tubić, S., Miladinov, Z., Dozet, G., Cvijanović, G., Đorđević, V., Cvijanović, M. (2014). Soybean Production and a Possibility to Economize the Use of Mineral Fertilizers. Ratar. Port. 51(3): 161-165. 
Eurostat (2016). Organic farming statistics - Statistics explained. http:// ec.europa.eu/eurostat/statistics-explained/index.php? title=Organic_farming_statisticsstable $=0 \&$ redirect $=$ no, accessed 1 December 2017.

Gosling, P., Shepherd, M. (2005). Long-term changes in soil fertility in organic arable farming systems in England, with particular reference to phosphorus and potassium. Agriculture, Ecosystems and Environment 105: 425-432.

Golijan, J., Živanović, L., Kolarić, L. (2017). Organic production of industrial crops in Serbia. Ratar. Pourt. 54(2): 68-72.

Hladni, N. (2016). Present status and future prospects of global confectionary sunflower production. 19th International Sunflower Conference.

Halvorson, A. D., Black, A. L., Kuprinsky, J. M., Merril, S. D., Tanaka, D. L. (1999). Sunflower response to tillage and nitrogen fertilization under intensive cropping in a wheat rotation. Agron. J. 91: 637-642.

Hammer, Ø., Harper, D., A., T., Ryan, P., D. (2001). PAST: Paleontological Statistics Software Package for Education and Data Analysis. Palaeontologia Electronica 4(1): 9pp.

IBM Corp. Released 2016. IBM SPSS Statistics for Windows, Version 24.0. Armonk, NY: IBM Corp.

Jalaluddin, M., Hamid, M. A. R. I. A. (2011). Effect of adding inorganic, organic and microbial fertilizers on seed germination and seedling growth of sunflower. Pakistan Journal of Botany, 43(6): 2807-2809.

Jocić, S., Miladinović, D., Kaya, Y. (2015). Breeding and Genetics of Sunflower. In: Martínez Force, E., Turgut Dunford, J., Salas, J. J. (Eds.): Sunflower Chemistry, Production, Processing, and Utilization. AOCS Press, Urbana, IL, pp. 1-25.

Joksimović, J., Atlagić, J., Jovanović, D., Marinković, R., Dušanić, N. Miklić, V. (2004). Path coefficient analysis of some head and seed characteristics in sunflower. Proceedings of 16th International Sunflower Conference, Fargo, North Dakota, USA pp. 525-530

Knapp, S., van der Heijden, M. G. (2018). A global meta-analysis of yield stability in organic and conservation agriculture. Nature Communications, 9(1): 3632.

Kramer, S., B., Reganold, J., P., Glover, J., D., Bohannan, B., J., Mooney, H, A. (2006). Reduced nitrate leaching and enhanced denitrifier activity and efficiency in organically fertilized soils. Proceedings of the National Academy of Sciences, 103(12): 4522-4527.

Lazić, B., Šeremešić, S. (2010). Organska poljoprivreda - danas i sutra. / Organic agriculture - today and tomorow. Savremena poljoprivreda 59 (5): 516-522.

Liebig, M., A., Doran, J., W. (1999). Impact of production practices on soil quality indicators. Journal of Environmental Quality 28: 1601-1609.

Lopez-Pereira, M., Sadras, V., O., Trapani, N., (1999). Genetic improvement of sunflower in Argentina between 1930 and 1995. Yield and its components. Field Crops Res. 62: 157-166.

Meier, U. (2001). Sunflower. In: Meier, U. (Ed.): Growth stages of mono- and dicotyledonous plants. BBCH Monograph. Julius Kühn-Institut (JKI) Quedlinburg

Murphy, K., M., Campbell., K., G., Lyon., S., R., Jones., S., S., (2007). Evidence of varietal adaptation to organic farming systems. Field Crops Research, 102(3): 172-177.

Marinković, R., Dozet, B., Vasić, D. (2003.). Oplemenjizanje suncokereta (Sunflower Breeding). Školska knjiga. Novi Sad.

Nam, U. V. (2015). Transforming our world: The 2030 agenda for sustainable development. Division for Sustainable Development Goals: New York, NY, USA.

National Research Council. 2010. Toward Sustainable Agricultural Systems in the 21st Century. Washington, DC: The National Academies Press. https://doi.org/10.17226/12832. accessed 6 Januar 2018

Nabloussi, A., Fernandez-Cuesta, A., El-Fechtali, M., FernandezMartínez, J., M., Velasco, L. (2011). Performance and seed quality of Moroccan sunflower varieties and Spanish landraces used for confectionary and snack food. Helia, 34: 75-82.
Niggli, U., Slabe, A., Schmid, O., Halberg, N. Schlüter, M. (2008). Vision for an Organic Food and Farming Research Agenda to 2025. IFOAM-EU \& FiBL. http://orgprints.org/13439/1/niggli-etal-2008-technology -platform-organics.pdf accessed on 25 January 2018.

Ozer, H., Polat, T., Ozturk, E. (2004). Response of irrigated sunflower (Helianthus annuus L.) hybrids to nitrogen fertilization: growth, yield and yield components. Plant Soil and Environment, 50(5): 205-211.

Pang, X. P., Letey, J. (2000). Organic farming challenge of timing nitrogen availability to crop nitrogen requirements. Soil Science Society of America Journal, 64(1): 247-253.

Pekcan, V., Evci, G., Yllmaz, İ. M., Kaya, Y. (2015). Developing confectionary sunflower hybrids and determination of their yield performances in different environmental conditions. Ekin Journal of Crop Breeding and Genetics, 2015(1-2): 47-5.

Pearson, K. (1901). On Lines and Planes of Closest Fit to Systems of Points in Space. Philosophical Magazine. 2 (11): 559-572

Ruffo, M., L., García, F., O., Bollero, G., A., Fabrizzi, K., Ruiz, R., A (2003). Nitrogen balance approach to sunflower fertilization. Communications in Soil Science And Plant Analysis, 34(1718): 2645-2657.

Reganold, J. P., \& Wachter, J. M. (2016). Organic agriculture in the twenty-first century. Nature Plants, 2(2): 15221.

Scheiner, J., D., Lavado, R., S. (1999). Soil water content, absorption of nutrient elements, and responses to fertilization of sunflower: a case study. J. Plant Nutr. 22: 369-377.

Simić, I. (2017). Organic Agriculture in Serbia, At a Glance 2017. National Association Serbia Organica. https://www.tehnologijahrane.com/ wp-content/uploads/2016/11/Organic-Agriculture-in-Serbia-At-aglance-2017.pdf accessed on 28 April 2018

Singh, P. R. (2012). Organic Fertilizers: Types, Production and Environmental Impact. In: Sing, P. R. (Ed.): Organic fertilizers. Nova Science Inc., New York. https://www.researchgate.net/ publication/274896698_Organic_Fertilizers_Types_Production_an d_Environmental_Impact, accessed on 27 March 2018

Shahzaman, M., Ishtiaq, M., Azam, A. (2017). Effect of different fertilizers on seed germination and seedling growth of sunflower (Helianthus annuus L.) from district Bhimber of Azad Jammu and Kashmir, Pakistan. International Journal of Botany Studies, 2(2): 10-15.

Škorić, D. (2012). Sunflower breeding. In: Škorić, D., Sakač, Z., (Eds.): Sunflower genetics and breeding. Novi Sad, Školska knjiga.

Willer, H., Lernoud, J., (Eds.) (2018). The world of onganic agriculture Statisticts and emerging trends 2018. Reshearche Institut of Organic Agriculture (FIBL), Frick, and IFOAM - Organics International, Bonn.

Zubillaga, M., M., Aristi, J., P., Lavado, R., S. (2002). Effect of phosphorus and nitrogen fertilization on sunflower (Helianthus annus L.) nitrogen uptake and yield. Journal of Agronomy and Crop Science, 188(4): 267-274. 


\section{Mogućnost gajenja konvencionalnih konzumnih hibrida suncokreta u uslovima organske proizvodnje: preliminarni rezultati istraživanja}

\section{Brankica Babec · Nada Hladni · Srđan Šeremešić · Milan Jocković . Nemanja Ćuk · Sonja Grozdenac · Vladimir Miklič · Bojan Vojnov}

Sažetak: Kako organska poljoprivreda predstavlja jedan od najodrživijih načina korišćenja poljoprivrednog zemljišta, svrha ovog istraživanja bila je poboljšanje proizvodnje konzumnog suncokreta u organskoj poljoprivredi. Prilikom istraživanja upoređen je prinos po biljci konvencionalnih hibrida u organskom i konvencionalnom proizvodnom sistemu. Nakon toga, upoređeni su masa 1000 semena, prinos po biljci i udeo jezgra konzumnih hibrida tretiranih sledećim đubrivima koja se koriste u organskoj proizvodnji: đubrivo životinjskog porekla $(\mathrm{G})$, đubriva na bazi aminokiselina i azota $(T)$ i mikrobiološko đubrivo $(N)$ sa ne tretiranom kontrolom $(C)$. Primena ovih đubriva povećala je prinos hibrida u odnosu na kontrolu, a najveći je zabeležen u kombinaciji tretmana G+N i G+T, a sve u organskom sistemu gajenja. NS Gricko je imao najmanji, statistički značajan, prinos semena po biljci u poređenju sa drugim hibridima, koji se značajno povećan tretiranjem $\mathrm{G}+\mathrm{N}$ dubrivima; isti rezultati su dobijeni kod hibrida NS Slatki i NS Leviathan. Preliminarni rezultati studije ukazuju da primena organskih đubriva može pozitivno uticati na prinos suncokreta u uslovima organske proizvodnje, što pokazuje da su dalja istraživanja neophodna.

Ključne reči: suncokret, organska proizvodnja,đubrenje, prinos semena, masa 1000 semena 